\title{
A COMPARATIVE ANALYSIS OF THE CERTIFICATION SYSTEMS OF GREEN SCHOOLS
}

\author{
IBRAHIM KOCABAS \& MEHTAP BADEMCIOGLU \\ Faculty of Education, Department of Educational Sciences, Education Management Inspection Division, \\ Yildiz Technical University, Turkey
}

\begin{abstract}
Sustainability is an approach that should not merely be limited to the design of buildings, but be a life style adopted by posterity. Individuals ought to have the consciousness to protect and preserve the natural resources of future generations. This is what will probably make studies on sustainability reach their targets. School buildings are critically important in achieving this goal in that they can enable future generations to be raised with an awareness of sustainability. This explains the reason why, in this study, the below leading green school certification systems and their criteria have been compared and examined: Leadership in Energy and Environmental Design, Collaborative for High Performance Schools, and Building Research Establishment Environmental Assessment Method. Five schools with these certificates were taken as examples, evaluated and compared. This study, in which descriptive survey model was employed, made it clear that the standards set for green schools serve similar purposes no matter when a green school certification system originated or which countries have adopted it. However, the below variables play an important role in the success of green school approach: attitudes of administrators, training pattern, location of the school, materials selection, and responsibilities of educators and learners. School buildings in Turkey should further be discussed in detail with these points in mind.
\end{abstract}

Keywords: sustainability, green schools, green school certification systems.

\section{INTRODUCTION}

Excessive consumption of natural resources due to global warming, environmental pollution and population growth necessitates a worldwide re-evaluation of the concept of development from different perspectives. It has been suggested that the building industry, which consumes about one third of the world's energy, has a role of ensuring environmental responsibility [1]. Movements initiated by the authorities of European Union and US on the use of resources in buildings help many countries to learn about environmentally friendly constructions. For instance, European Union has put into practice the Energy Performance of Buildings Directive in order to maximize energy savings and limit greenhouse gas emissions [2]. It is underlined that the aim of this directive is the construction of new buildings that will consume nearly zero energy until 2020 [3].

Green buildings are defined as structures that are designed to remove the negative effects of the construction industry on the environment, as well as on human health state [4]. This makes it necessary for a building to be sensitive to the environment in view of its design, construction processes, repair and maintenance, as well as the way it uses natural resources. A green building is one that has the least impact on the environment as long as it exists [1]. It is noteworthy that World Green Building Council (WGBC), which is advancing green buildings firstly as a reaction to the waste of energy and natural resources, specifies that this concept has changed over time and the Council now emphasizes effective energy use more than ever [5].

A school building becomes "green" when it saves energy, resources and money, and creates a healthy environment that can support learning. The provision of the teachinglearning process in healthy buildings reduces workforce loss and students' failure [6]. 
Moreover, a green school building encourages waste management efforts and recycling, provides drinking water saving devices, as well as gathering and using rain water for the benefit of a region and the local people living in such. Furthermore, it helps students to develop environmental literacy and enhance their environmental awareness [7].

There are more than 30 globally accepted green building standards and certifications that stakeholders of the building industry may refer to and take into consideration. Below are some of the widely used ones: Green Building Challenge (GBC), Leadership in Energy and Environmental Design (LEED), Building Research Establishment Environmental Assessment Method (BREEAM), Building for Environmental and Economic Sustainability (BEES), Sustainable Building Tool-Canada (SBTool), Life Cycle Assessment (LCAid), Comprehensive Assessment System for Built Environment Efficiency (CASBEE), ECOQUANTUM, ECOPROFILE, and GREENSTAR.

This study is aimed at analysing the similarities and differences between the green school certification systems of LEED, Collaborative for High Performance Schools (CHPS), and BREEAM. Data generated from this study is expected to contribute to the creation of healthy school buildings in Turkey and to raising individuals who are sensitive to the environment. The following research questions provide the frame for this study:

- When and where were these certification systems developed?

- Who developed the systems?

- What are the purposes of the systems?

- Who are the stakeholders of the systems?

\section{METHOD}

\subsection{Research design}

The descriptive survey model was used in this study so as to compare three green school certification systems. This is an approach that aims to describe a past or currently existing case and enables the events and circumstances to be investigated in detail [8].

\subsection{The instrument}

Data have been obtained by literature review. This process is initiated by gathering data and continued by discussing its importance, establishing its relation with the problem, and finally classifying the information stages. In this technique, it is aimed to collect data by examining the existing sources, documents and papers [9]. The typical sampling method, developed by Patton, was used in this study. The purpose of this method is not to select typical situations and generalize the universe. It is to have an idea about a certain area by studying on the average conditions or to provide information for those who do not have sufficient knowledge about an area, an issue, a practice or an innovation [10].

\subsection{Data analysis}

Data have been analysed by using the descriptive analysis approach. This approach allows the data to be organized according to the themes that emerge from the research or interview questions [11]. By means of this approach, the data obtained from this study were selected, and organized. Similarities and differences between the certification systems were then analysed, compared and interpreted. 


\section{FINDINGS}

\subsection{LEED}

Leadership in Energy and Environmental Design (LEED) was established in 1994 by two non-profit organizations of the US Green Building Council (USGBC) and The Natural Resources Defence Council (NRDC). A regularly renewed voluntary enterprise, LEED was advanced in 2007 by the American Green Building Council and lent its name to green building evaluation systems in general [12].

Below is a list of LEED's priority criteria: physical environment, society, transportation, green energy, heat islands, light pollution, water usage, greenhouse gas emissions, materials, waste, indoor air quality, as well as quantity and user comfort. Data, such as construction records, engineering calculations, and energy model reports, are required by LEED for a project to be implemented, since drawings and diagrams of such are created by means of these data [12], [13].

The rules stipulating how a LEED certificate can be obtained can be accessed from the LEED Reference Guide or USGBC's website. When the required documents are collected, they are submitted to the USGBC over the internet. Then, a six-month review process is started without any field inspection. Each credit, such as indoor air quality, corresponds to a set score, and a certificate is awarded according to the total score that the project has received [12]. Scoring is based on a 100-point system. Ranges and total points vary according to the type of the building. There are four types of certificates: Certified, Silver, Gold, and Platinum [13]. Table 1 shows LEED grades and point distribution.

Another feature of the LEED Certification System is regional credits. The distribution of points is based on strategies that increase energy efficiency and reduce $\mathrm{CO}_{2}$ emissions. Each credit is evaluated with a list of thirteen environmental impact categories, including climate change, indoor quality, resource consumption, and water usage [13].

There are various organizations that determine school design standards, taking into account the level-of-acceptance criteria for environmental health. But LEED certification system is used for all types of buildings, such as existing buildings, commercial interiors, schools, houses, new constructions and renovated buildings, so its scope is rather broad when compared to other systems, such as Collaborative for High Performance Schools (CHPS), Energy Star (ES), and Georgia Energy Code Compliance (GECC) [14]. In order to understand whether a school is compatible with LEED, the following six standard areas are considered: energy and atmosphere, building sustainability, indoor air quality, innovative design, materials and resources, and water savings [15].

One of the schools certified for LEED certification is Woodrow Wilson High School (Fig. 1). Situated in Dallas, USA, the school started education in 1935. A project was launched in 2008 in order to create a healthy educational environment, and approximately $7,000 \mathrm{~m}^{2}$ of area was renovated within three years. In 2010, it was approved as a historic building, and on account of its renovation efforts, the school was entitled to receive a gold certificate in 2011.

A total of 93.5 million \$ was spent on the renewal process of Woodrow Wilson High School. The prominent elements in this project are as follows: adapting and reusing old equipment, making links between buildings more accessible, using technologies that enable efficient use of energy, using large windows and acoustic panels for natural lighting, as well as having a greenhouse, green roof and photovoltaic panels. Three different buildings of the school (the auditorium, gymnasium, and academic building) were designed to receive LEED certification. 
Table 1: LEED rating.

\begin{tabular}{|c|c|}
\hline LEED Rating & Score \\
\hline Certified & $40-49$ \\
\hline Silver & $50-59$ \\
\hline Gold & $60-79$ \\
\hline Platinum & 80 and over \\
\hline
\end{tabular}

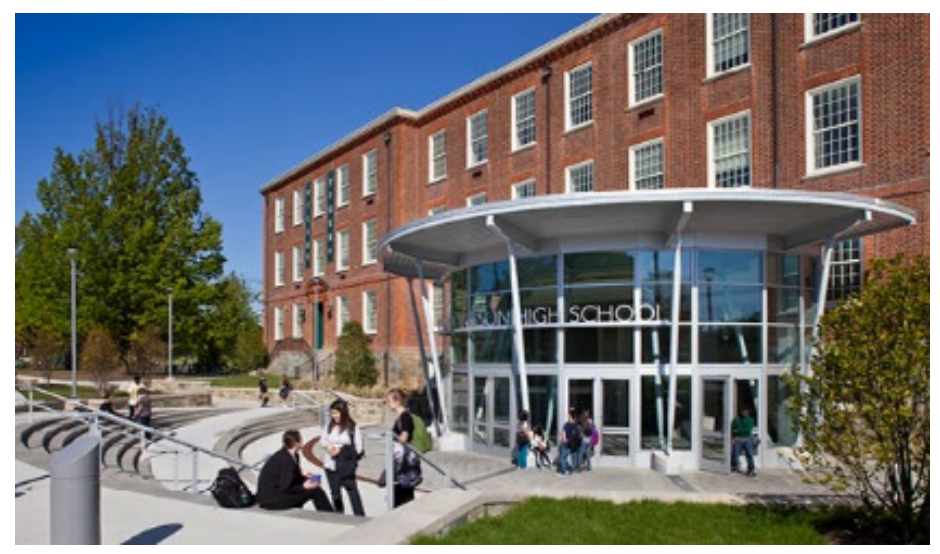

Figure 1: Woodrow Wilson High School - Main Entrance [16].

Table 2: LEED point distribution of Woodrow Wilson High School.

\begin{tabular}{|c|c|}
\hline LEED Evaluation Criteria & Score \\
\hline Sustainable Sites & $17 / 24$ \\
\hline Water Efficiency & $9 / 11$ \\
\hline Energy and Atmosphere & $3 / 33$ \\
\hline Materials and Resources & $7 / 13$ \\
\hline Indoor Environmental Quality & $9 / 19$ \\
\hline Innovation and Design Process & $6 / 6$ \\
\hline Regional Priority Credits & $2 / 4$ \\
\hline
\end{tabular}

Table 2 shows the distribution of LEED scores obtained by this high school [17] (www.new.usgbc.org/projects/woodrow-wilson-high-school).

According to Table 2, the school earned a full score from the innovation and design process section. This score is followed by those from the sustainable sites and water efficiency sections. However, it received some low scores, especially from the energy and atmosphere section.

Knowing that the support of its students was an important factor in achieving the set target, the school management included them in the process of renovation. For this reason, 35 volunteer students were educated and assigned to convey information to other students on the green features of the school. A guidebook was also prepared and distributed to make them knowledgeable about the "green school approach" [17]. 


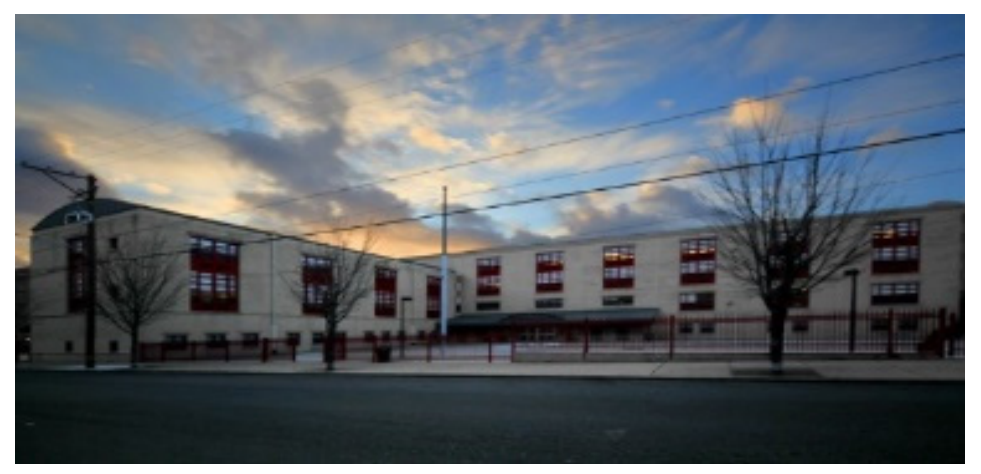

Figure 2: Thurgood Marshall Elementary School - Main Entrance [18].

Another school that has qualified for LEED certification is the Thurgood Marshall Elementary School (Fig. 2) in Philadelphia, USA. Built in 1997, the school has four storeys and an area of $114,000 \mathrm{~m}^{2}$. More than 100 teachers and staff are employed to serve 700 students. It was decided in 1989 that the building would be renewed in accordance with LEED Building Operations and Maintenance (O\&M) rating system. This project was the first to be accomplished according to the criteria set by the above-mentioned rating system [19].

The principal, assistant principals, civil engineers, and teachers became the members of this project, the scheduled duration of which was two years. One of the most important sustainability goals for this project was to provide a high-performance learning and working environment for students, teachers, and staff. Another important goal was to reduce energy costs. Developing energy-related systems in the building was stated as the third goal. According to the O\&M rating system, Thurgood Marshall Elementary School was qualified to receive a certificate upon the completion of the project. Of the schools that received this certificate, Thurgood Marshall Elementary was the first in Pennsylvania and the fifth in the United States [18].

It is among the strategies of LEED to be involved with management and maintenance operations. During the certification process, it also pays attention to how students adopt the green school approach. According to this strategy, one student in each class is assigned as a Green Monitor. Each Green Monitor ensures that other students are sensitive to energy saving and recycling [19]. LEED point distributions of Thurgood Marshall Elementary School are listed in Table 3.

Table 3: LEED point distributions of Thurgood Marshall Elementary School.

\begin{tabular}{|c|c|}
\hline LEED Evaluation Criteria & Score \\
\hline Sustainable Sites & $8 / 26$ \\
\hline Water Efficiency & $8 / 14$ \\
\hline Energy and Atmosphere & $12 / 35$ \\
\hline Materials and Resources & $4 / 10$ \\
\hline Indoor Environmental Quality & $8 / 15$ \\
\hline Innovation and Design Process & $6 / 6$ \\
\hline Regional Priority Credits & $1 / 4$ \\
\hline
\end{tabular}




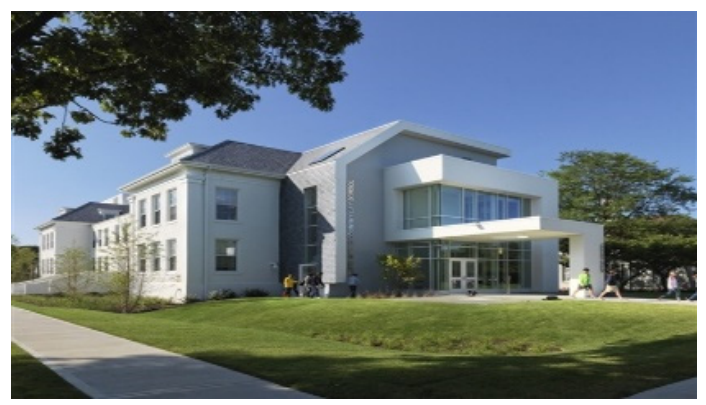

Figure 3: North Shore Country Day School - Entrance Gate [20].

By looking at the LEED point distributions of the Thurgood Marshall Elementary School, it can be seen that the school has received a full score from the innovation and design process section. This is followed by water efficiency and indoor environmental quality sections. However, the score of the school in the regional priority credits section is low.

North Shore Country Day School in the state of Illinois, USA is another one of those schools that has been awarded with a LEED certificate (Fig. 3). Donations were collected in 2008 to improve the educational environment of the school. As a result of the donation efforts, 30 million US dollars were raised to realise the project, and an area of about 65,000 $\mathrm{m}^{2}$ was renewed in 15 months. The school building then received a silver LEED certificate in 2011.

As can be seen from the table, the school obtained high scores from the innovation and design process, materials and resources, and indoor environmental quality sections, whereas it received a low score from water efficiency.

The incentive that lead the school to apply for LEED certification was interesting and noteworthy. The administration decided to apply for the LEED certification so that the school could demonstrate its commitment to the goals of sustainability, which were included in its strategic plan. In order to receive this certification, they achieved a structure that would support coexistence and new forms of education [21]. In other words, the design of North Shore Country Day School makes it possible to combine traditional and progressive education [20].

The building was designed to maximize the experience of students with an interactive education [20]. Before this process, opinions of the users were asked for, and they stated that they wanted more colours, daylight, and larger environments. The design was accomplished

Table 4: LEED point distributions of North Shore Country Day School.

\begin{tabular}{|c|c|}
\hline LEED Evaluation Criteria & Score \\
\hline Sustainable Sites & $10 / 24$ \\
\hline Water Efficiency & $4 / 11$ \\
\hline Energy and Atmosphere & $11 / 33$ \\
\hline Materials and Resources & $8 / 13$ \\
\hline Indoor Environmental Quality & $11 / 19$ \\
\hline Innovation and Design Process & $4 / 6$ \\
\hline Regional Priority Credits & $2 / 4$ \\
\hline
\end{tabular}


keeping these firmly in mind, and multi-purpose environments, including a large staircase called $\mathrm{V}$, were planned.

The design team did not ignore the effect of natural light on student achievement, and made the walls of the new classes from glass. It is now possible in this school to receive more daylight for longer periods of time. Moving chairs and tables were used instead of the classic immobile ones. Apart from these, interactive whiteboards, projection screens, and video conferencing tools were used to increase the flexibility of classrooms. Approximately $90 \%$ of the materials used during the construction were recycled. The wood used in the construction was certified as coming from sustainable forests. The roof of the building was covered with some sort of recycled material durable for 50 years [22].

\subsection{CHPS}

Collaborative for High Performance Schools (CHPS) was developed in 2001 in California. The aim of this system is to ensure that school buildings to be renovated or renewed have higher performance than the previous ones. Actually, this system, which was based on LEED, only aimed to assess the sustainability performance of school buildings in California. But later on, it also helped schools in the state to achieve grid neutral energy performance, which means that a school is able to produce its own electricity [6]. Up to now, 46 schools have been awarded with CHPS certificate in the USA. CHPS criteria have been adopted by eleven states, including California, Washington, New York, and Massachusetts. Although it is a fairly new evaluation system, the minimum requirements for CHPS have become compulsory for the school building industry in many regions, such as Los Angeles, Burbank, Santa Ana, and San Diego.

Unlike LEED, the CHPS system can only be used to evaluate school buildings. Instead of LEED's grades (certified, silver, gold, platinum), CHPS has a Pass or Fail evaluation to determine whether a building is entitled to obtain a certificate. The most important difference between LEED and CHPS is that building owners have the opportunity to evaluate their own buildings in the latter system. Besides this, guiding publications by LEED are targeted at engineers and architects only, whereas those by CHPS are meant for everyone.

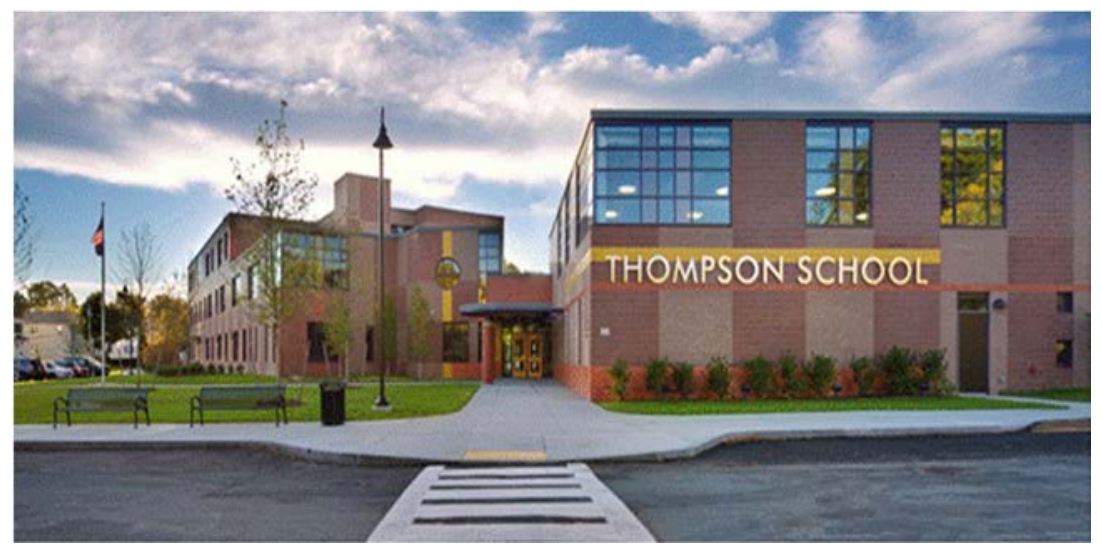

Figure 4: Thompson Elementary School - Main Entrance [23]. 
Situated in Arlington, Massachusetts, Thompson Elementary School (Fig. 4) was entitled to receive the CHPS Verified Leader Certification in 2013. The process of redesigning the school building in accordance with the CHPS standards was completed in 2013, which cost slightly more than 20 million US dollars. Sustainable materials were used during this process, and the school was afterwards able to reduce its energy and water consumption. A CHPS Verified Leader Certification is given to a school that scores at least 50 points in the CHPS system, and, in return, this certificate provides a high level of recognition for that school and its projects. Thompson Elementary School is one of the two schools that have received CHPS Verified Leader Certification [23].

During the process of construction, resources within 500 miles of the school were used as building materials. Since the vast majority of the wood material used was recycled, the school was certified by Forest Stewardship Council. During the interior design process, acoustical considerations were taken into account, and an optimum learning environment was created. After the completion of the construction, necessary arrangements were made to ensure indoor air quality [22].

The old school building had single-sided windows, and there were gaps in the outer walls. However, the new building now has double-sided windows that provide the highest level of natural lighting, natural scenery and outdoor connection. Besides, the walls were plastered with some environmentally friendly material. What is more, the energy management system installed in the building helped reduce energy consumption for heating and cooling [23].

\subsection{BREEAM}

Building Research Establishment Environmental Assessment Method (BREEAM) is the first of its kind to determine the effects of construction processes on the environment [24]. It was developed in 1990 by the Building Research Establishment (BRE) as a tool to measure the sustainability of new non-residential buildings in the UK. The system has been continuously updated in line with the British building regulations. In the year 2008, it was thoroughly upgraded and thereafter named as BREEAM 2008 [25]. The below are the purposes of BREEAM: reducing the life cycle environmental impacts of buildings, providing a reliable environmental label for them, and revitalizing the demand for sustainable buildings [24]. The below architectural constructions are in the scope of BREEAM: new buildings, apartments, schools, dormitories, nursing homes, hospitals, prison buildings, and industrial structures [26].

BREEAM does not entail a priority list as does LEED. The requirements of BREEAM are as follows: construction records, architectural drawings and diagrams, engineering calculations, energy model report, written explanations about the project, site visits, and filled BREEAM documents. The BRE's regulations, publications, standards and certification schemes are controlled by the BRE Global Sustainability Board [2], [25]. BREEAM assessment experts are trained by the BRE.

Any building that has applied for a BREEAM evaluation needs the help of a certified evaluation expert. The expert brings together all the information about a project that will show the BREEAM criteria have been met. The BRE employees guided by the information provided by the expert perform two controls. However, there is an extra requirement for projects from outside the UK to pass a pre-qualification control showing that local laws governing the applicant's country are equivalent to BREEAM criteria [25], [27]. In contrast to LEED, BREEAM uses the following weighted scoring system. 
Table 5: BREEAM rating.

\begin{tabular}{|c|c|}
\hline BREEAM Rating & \% Score \\
\hline Unclassified & $<30$ \\
\hline Pass & $\geq 30$ \\
\hline Good & $\geq 45$ \\
\hline Very Good & $\geq 55$ \\
\hline Excellent & $\geq 70$ \\
\hline Outstanding & $\geq 85$ \\
\hline
\end{tabular}

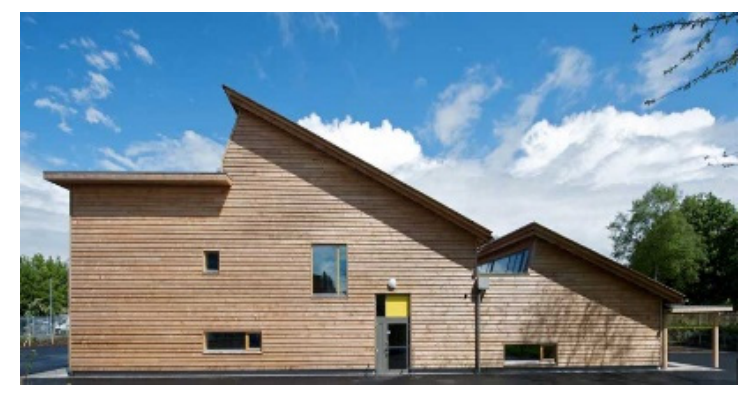

Figure 5: St. Luke Elementary School - Main Entrance [28].

Located in Wolverhampton, United Kingdom, St. Luke Elementary School (Fig. 5) was found eligible to receive the BREEAM certificate in 2012, and became the first BREEAM Excellent Primary School in Britain. Designed by Architype, the school has a capacity of 450 students, and the two-storeyed building is made totally of timber [28]. The choice of such hot materials as wood has reduced energy consumption for heating and cooling. This is coupled with the correct use of bright colours and natural light.

Great importance was attached to the internal design of this school. Instead of classical corridors, common areas were created in the school that encourage communication and interaction among students. Such areas as the library and cafeteria were also decorated to support communication among students [27].

The wood used in the construction of the school was obtained from a kind of fir tree harvested from British forests. Natural products were preferred to paint the school. Ventilation is controlled by a building management system. In addition to these, biomass is used in the school as a means of heating [26]. BREEAM has recognized the school as having an ecologically efficient building on account of its below-mentioned features: geometric shape, carbon-neutral structure, triple glazed windows, heating system, and insulation.

The evaluation methods employed by the certification systems of LEED, CHPS, and BREEAM are examined comparatively in table 6 . The comparison reveals that, no matter where and when these systems may have been developed, they have plenty of similarities and all pay attention to the below criteria: sustainability of a building design, effectiveness of methods employed in building evaluation, and provision of public awareness for sustainability. 
Table 6: Comparison of the green school certification systems.

\begin{tabular}{|c|c|c|l|l|l|}
\hline $\begin{array}{c}\text { Evaluation } \\
\text { System }\end{array}$ & $\begin{array}{c}\text { Time of } \\
\text { Origin }\end{array}$ & Country/State & $\begin{array}{c}\text { System } \\
\text { Developer }\end{array}$ & \multicolumn{1}{|c|}{ Aims } & Stakeholders \\
\hline LEED & 1994 & USA & $\begin{array}{l}\text { U.S. Green } \\
\text { Building } \\
\text { Council } \\
\text { (USGBC) }\end{array}$ & $\begin{array}{l}\text { Serves as a tool } \\
\text { for the design, } \\
\text { construction and } \\
\text { operation of green } \\
\text { buildings* }\end{array}$ & $\begin{array}{l}\text { Building } \\
\text { project team, } \\
\text { architect, } \\
\text { designer, } \\
\text { proprietor, } \\
\text { contractor }\end{array}$ \\
\hline CHPS & 2001 & California & $\begin{array}{l}\text { California } \\
\text { Energy } \\
\text { Commission }\end{array}$ & $\begin{array}{l}\text { Evaluates the } \\
\text { performance of } \\
\text { school buildings } \\
\text { in terms of } \\
\text { sustainability in } \\
\text { California }\end{array}$ & $\begin{array}{l}\text { Building } \\
\text { owner, } \\
\text { building } \\
\text { operator }\end{array}$ \\
\hline BREEAM & 1990 & $\begin{array}{l}\text { United } \\
\text { Kingdom }\end{array}$ & $\begin{array}{l}\text { Building } \\
\text { Research } \\
\text { Establishment } \\
\text { (BRE) }\end{array}$ & $\begin{array}{l}\text { Sets the best } \\
\text { practice for a } \\
\text { sustainable } \\
\text { building design, } \\
\text { construction and } \\
\text { operation, and } \\
\text { sets } \\
\text { comprehensive } \\
\text { standards for a } \\
\text { building's } \\
\text { environmental } \\
\text { performance }\end{array}$ & $\begin{array}{l}\text { Building } \\
\text { owner, } \\
\text { building } \\
\text { operator }\end{array}$ \\
& & & &
\end{tabular}

* Decisions are taken based on consensus.

The five certified schools that have been examined in this study are Woodrow Wilson High School, Thurgood Marshall Elementary School, North Shore Country Day School, Thompson Elementary School, and St. Luke Elementary School. The examination demonstrates that, however different it may at first seem, the way the concept of sustainability is implemented in each school is similar to a certain degree. For instance, it can be said that the certification process in each school necessitated the below listed criteria to be met: participation of many, if not all, administrators, revision of the education model, the right decisions to be taken on the settlement of a new building, finding solutions to interior design problems, appropriate selection of materials, and sharing of responsibilities between instructors and students. It may be asserted that schools in Turkey should be examined with all these considerations in mind as explained in detail in the next section.

\section{RESULTS AND DISCUSSION}

The common aspect of green building certification systems is that they set specific criteria for assessing the needs of a school building as well as those of other building types. There is a general similarity in the way certification systems deal with certain matters; nevertheless, the evaluation methods and criteria employed differ to a certain degree [29]. The similarities between these systems are that all of them emphasize the importance of below criteria: constructing a robust building, providing adequate sunlight and good indoor air quality, selecting appropriate colours, ensuring an efficient energy design, and using the building as a good teaching tool. These are significant issues as far as children are concerned, since they 
are the ones who mostly use school buildings. Certification systems, such as CHPS, LEED, and BREEAM, attach considerable importance to solar light standards due to the positive effects of this kind of light on eye health and vision, hormones, and concentration on lessons. The qualities of a building envelope which influences energy efficiency as well as indoor air quality are dealt with in a similar way by various certification systems. However, while LEED and BREEAM present ratings for the prevention of noise transmission in the design of building shells and dividing walls, sound insulation is required in certain standards set by CHPS in order to provide an environment in which teachers can teach without having to raise their voice during the lesson and students can easily communicate with each other.

As a result of this present study, the following conclusions have been reached regarding the mutual aims of and standards set by green school certification systems:

- The first and foremost aim is to protect and preserve the environment while constructing or using a green school,

- Natural light should be made use of as far as possible. This affects the physical and mental health of the building users positively by increasing their performance and success,

- Non-destructive methods should be employed in order to increase indoor air quality. Good indoor air quality may prevent building users from being afflicted by asthma or allergy-related disorders,

- It is important to equip the building with top-quality water-saving devices,

- It is essential to minimize energy consumption and utilize renewable energy sources effectively,

- Noise coming from outside should be prevented,

- Noise level in class should be within acceptable limits,

- Equipment to be used in the school building and in classes should be selected from material that will not harm student-teacher health or the environment,

- The green school building as a whole and its new atmosphere should discourage student/teacher absences,

- The green school is expected to enable future generations to be raised with an awareness of sustainability.

In brief, green schools are aimed at providing qualified environmental education for students so that a permanent solution to environmental problems could be found in future. Another aim is to make them conscious about efficiently using such energy resources in schools as water, electricity and natural gas. A third aim is to give education to students in a healthier environment. As far as some green school examples in Turkey are concerned, it can be asserted that the concept of sustainable architecture is not well understood. It is a general assumption in Turkey that a sustainable building has advanced technology, it consumes less energy and/or it is simply an intelligent structure. That is to say, the relationship of a building with the social, cultural, environmental and economic realities of the place of its construction are not much considered. Lack of appropriate architectural and planning policies for a sustainable development approach is one of the factors that causes the green school concept not to be understood sufficiently. Because Turkey is a developing country and dependent on outside energy, it should focus on green schools that have healthier physical conditions and should raise awareness for the protection of the environment. It would be a good start if Turkish schools were provided with some technical and architectural knowledge that can be made use of in the renewal of existing school buildings. 
This could provide present and future generations with the opportunity to achieve environmental targets.

\section{ACKNOWLEDGEMENT}

The current study has been supported by the Scientific Research Projects Coordination Centre, Yildiz Technical University.

\section{REFERENCES}

[1] Patel, C. \& Chugan, P.K., Measuring awareness and preferences of real estate developers for green buildings over conventional buildings. Consumer Behaviour and Emerging Practices in Marketing, pp. 332-341, 2013.

[2] ISO. 2010. Yapi Malzemeleri Sanayi. Istanbul: ISO Yayinlari.

[3] Cakmanus, I., Kas, I., Kunar, A. \& Gulbeden, A., Yuksek performansli surdurulebilir binalara iliskin bir degerlendirme. http://www.cakmanus.com.tr/doc/yuksekperformanslibinalara-iliskin-bir-degerlendirme.pdf. Accessed on: 2 Apr. 2016.

[4] Vyas, S., Ahmed, S. \& Parashar, A., BEE (Bureau of Energy Efficiency) and green buildings. International Journal of Research, 1, pp. 23-32, 2014.

[5] WBGC. 2013. The Business Case for Green Building: A Review of the Costs and Benefits for Developers, Investors and Occupants. Washington, DC.

[6] Arslan, Z.C., Uluslararasi degerlendirme sistemlerinde surdurulebilir egitim yapilari. Ekolojik Yapilar ve Yerlesimler Dergisi, 2010.

[7] Design and Health. http://www.aia.org/aiaucmp/groups/aia/documents/pdf/ aiab093466.pdf. Accessed on: 16 Oct. 2015.

[8] Erkus, A., Bilimsel Arastirma Sarmali. Ankara: Seckin, 2005.

[9] Balci, A., Sosyal Bilimlerde Arastirma, Yontem, Teknik ve Ilkeler, (2nd edt). Ankara: 72 TDFO Bilgisayar-Yayincilik. 1997.

[10] Patton, M.Q., How to Use Qualitative Methods in Evaluation. Newbury Park, CA: Sage, 1987.

[11] Yildirim, A., Simsek, H., Sosyal Bilimlerde Nitel Arastirma Yontemleri. Ankara: Sozkesen, 2003.

[12] Cevre ve Sehircilik Bakanligi. Cevresel gurultunun degerlendirilmesi ve yonetimi yonetmeligi. Cevre Yonetimi Genel Mudurlugu, Ankara. P. 29.

[13] Anbarci, M., Giran, O. \& Demir, I.H., Uluslararasi yesil bina sertifika sistemleri ile Turkiye'deki bina enerji verimliligi uygulamasi. E-Journal of New World Sciences Academy NWSA-Engineering Sciences, 7(1), pp. 158-176, 2012.

[14] Cevre ve Sehircilik Bakanligi. Yesil binalar. Surdurulebilir Uretim ve Tuketim Yayinlari, p. 5, 2011.

[15] Chan, T., An Examination of Green School Practices in Atlanta Schools. http://files.eric.ed.gov/fulltext/ED543509.pdf. Accessed on: 12 Dec. 2015.

[16] Cox Graae Plus Spack Architects. http://cgsarchitects.com/project/woodrow-wilsonhigh-school/?c=k-12-education. Accessed on: 21 May 2016.

[17] LEED BD+C: Schools v3-LEED 2009. http://new.usgbc.org/projects/woodrowwilson-high-school Accessed on: 19 Apr. 2016.

[18] The Sheward Partnership, Sustainability-Education http://www.theshewardpartnership.net/?page_id=145. Accessed on: 6 May 2016.

[19] LEED O+M: Existing Buildings v3-LEED 2009 http://www.usgbc.org/projects/ thurgood-marshall-elementary-school?view=stories. Accessed on: 12 Feb. 2016.

[20] North Shore Country Day School Project. http://thethirdteacherplus.com/index/\#/nscd/ Accessed on: 10 Jan. 2016. 
[21] North Shore Country Day School-My School. http://www.nscds.org/podium/ default.aspx?t=147100\&rc=0. Accessed on: 11 Feb. 2016.

[22] North Shore Country Day School-LEED Project. www.winnetka.suntimes.com Accessed on: 9 Feb. 2016.

[23] Energy Efficiency Policy Brief: Hot Topics and Key Opportunities for States. http://www.neep.org/sites/default/files/resources/Thompson\%20Elementary\%20Case \%20Study.pdf. Accessed on: 27 Jul. 2016.

[24] BREEAM. BREEAM new construction non-domestic buildings technical manual. SD 5073-2.0, 24, 2011.

[25] Erten, D., Henderson, K. \& Kobas, B., Uluslararasi yesil bina sertifikalarina bir bakis: Turkiye icin bir yesil bina sertifikasi olusturmakicin yol haritasi. 5th International Conference on Construction in the 21 st Century (CITC-V), May 20-22, 2009. Istanbul, Turkey, 2009.

[26] Sev, A. \& Canbay, N., Dunya genelinde uygulanan yesil bina degerlendirme ve sertifika sistemleri. Yapi Dergisi. 45, 2009.

[27] Saunders, T., A Discussion document comparing international environmental assessment methods for buildings. BRE Global, pp. 1-46, 2008.

[28] Floornature Architecture and Surfaces. http://www.livegreenblog.com/sustainablearchitecture/st-lukeand39s-elementary-school-by-architype-is-the-first-breeamexcellent-primary-school-in-britain-7629/. Accessed on: 20 Oct. 2016.

[29] Sahin, E. \& Dostoglu, N., Okul binalari tasariminda surdurulebilirlik. Uludag Universitesi Muhendislik Fakultesi Dergisi, 20(1), pp. 75-91, 2017. 